DOI 10.18551/rjoas.2020-01.16

\title{
THE EFFECTS OF ROOTSTOCK AND WATERLOGGING DURATION ON CALCIUM ABSORPTION AND THE ROTTING OF BOTTOM FRUIT (BLOSSOM END ROT) OF TOMATO PLANT (SOLANUM LYCOPERSICON L.) CERVO VARIETIES
}

\author{
Latifah Evy*, Handoko \\ Assessment Institute for Agricultural Technology of East Java, Indonesia \\ Melati Rima \\ Faculty of Agriculture, University of Khoirun, Indonesia \\ *E-mail: epilatip08@gmail.com
}

\begin{abstract}
This study was conducted to determine the effect of the Ca element on the blossom end rot of tomatoes which was grafted using different eggplant rootstocks. The Calcium deficiency decreases merismatic tissue growth and reduces yields. This experiment used a factorial randomized design which consisted of two factors. The first factor was grafting tomatoes of Cervo variety with different rootstocks (A). The rootstock of the eggplant was EG 203 lines (A1) and Gelatik variety (A2). The second factor was waterlogging (B), consisting of no waterlogging (B0), 2-day-waterlogging in the vegetative phase (B2V), 2-day-waterlogging in the flowering phase (B2B), 2-day-waterlogging in the fertilization phase (B2H), 4-daywaterlogging in vegetative phase (B4V), 4-day-waterlogging in the flowering phase (B4B), and 4-day-waterlogging in the fertilization phase $(\mathrm{B} 4 \mathrm{H})$. The total combinations of the two treatments were 14 treatments. The results of the study show that tomato plants grafted to two kinds of rootstock, namely EG 203 line and Gelatik variety which were waterlogged for 4 days, benefitted from the treatment because Gelatik eggplant roots could absorb more Calcium, so as to reduce the number of blossom end rot on the base of the tomato fruit. Furthermore, tomato plants with EG 203 line as rootstock had better ability to absorb Calcium than tomato plants grafted to Gelatik rootstock under both normal condition and waterlogging treatment for 2 days in several phases.
\end{abstract}

\section{KEY WORDS}

Grafted tomato, waterlogging, calcium absorption, blossom end rot.

Potassium (K), Magnesium (Mg), and Calcium (Ca) are important nutrients for the production of tomatoes. Deficiency of these elements usually occurs due to the lack of supply or the antagonistic nature of the elements, thereby reducing the growth, yield, and quality of tomatoes. Hao and Papadopoulos (2003) report that Calcium deficiency decreases merismatic tissue growth, reduces yields, and causes necrosis in the young leaves in more severe cases. Cultivars that are vulnerable on certain seasons and environmental conditions cause economic losses (Taylor and Locascio, 2004). Fruit tip rot is a physiological disorder in tomato plant. Fruit rotting symptoms first appear as necrotic tissues developing in the placenta distal and pericarp (Willumsen et al., 1996). Ikeda and Osawa (1988) state that Calcium (Ca) deficiency is one of the causes of fruit tip rot, in addition to nutritional factors and the environment around the roots. Calcium deficiency is a major cause of fruit tip rot, where the fruit with a disease has lower Calcium level than the healthier fruit (Saure, 2001). The low supply or absorption and transport of Calcium to the fruit, especially to the distal tissue, can cause fruit to rot. Calcium trans-location from root to fruit through xylem relies on the availability of water; therefore, water is the dominant factor in regulating the movement of Calcium (Bartal and Pressman, 1996). Water stress which inhibits the absorption of Calcium stimulates the rotting process of the tip of the fruit (Adams and Ho, 1992). Increased levels of Potassium (K) in nutrient solution can slow down the fruit tip rotting process. As explained by Sonneveld and Voogt (1991), also justified by Nonami et al. (1995), high Potassium (K) and 
Calcium $(\mathrm{Ca})$ levels can reduce fruit tip rot, although there is no interaction between the two elements. The solution to mitigate the risk arising from poor water conditions in the tomato planting area is by performing grafting.

Vegetable grafting is performed to improve soil resistance from adverse conditions such as salinity, excessive humidity, and low soil temperature, and also to boost nutrient and water uptake, as well as to increase crop resistance (Abdelmageed and Gruda, 2009). Grafting with interactions between the upper stem and lower stem affects various physiological processes of plants, such as absorption and transfer of nutrients and water, hormone synthesis, photosynthesis, and other metabolic processes (Petropoulos et al., 2012). The selection of rootstock must consider the suitability of rootstock combination based on climate and geographical conditions. The selection of rootstock is very important for successful grafting because it affects the availability of nutrients, crop yields, and fruit quality (Hartmann and Schwarz 2009). This influence is mainly associated with the scion and rootstock, which affect various plant's physiological processes such as absorption of nutrients and water, hormone synthesis, photosynthesis, and other metabolic processes (Petropoulos et al., 2012). Thus this study was conducted to determine the effect of the $\mathrm{Ca}$ element on the blossom end rot of tomatoes which was grafted using different eggplant rootstocks.

\section{MATERIALS AND METHODS OF RESEARCH}

Place and Time of implementation. The study was conducted in a green house in Wagir sub-district of Malang at an altitude of 400 meters above sea level. Plant materials consist of the scion and rootstocks. The rootstock was taken from an eggplant (Solanum melongena L.) EG 203 line derived from AVRDC (The Word Vegetable Research) and local eggplant Gelatik variety, while the scion was harvested from tomato plant of Cervo variety.

Treatment: This experiment used a factorial randomized design which consisted of two factors. The first factor was grafting tomatoes of Cervo variety with different rootstocks $(A)$. The rootstock of the eggplant was EG 203 lines (A1) and Gelatik variety (A2). The second factor was waterlogging (B), consisting of no waterlogging (B0), 2-day-waterlogging in the vegetative phase (B2V), 2-day-waterlogging in the flowering phase (B2B), 2-daywaterlogging in the fertilization phase $(\mathrm{B} 2 \mathrm{H})$, 4-day-waterlogging in vegetative phase (B4V), 4-day-waterlogging in the flowering phase (B4B), and 4-day-waterlogging in the fertilization phase $(\mathrm{B} 4 \mathrm{H})$. The total combinations of the two treatments were 14 treatments. The stages of the study began with the first step where Cervo variety tomato was grafted to the rootstock of the EG 203 line and Gelatik variety. The grafting process took place for \pm 15 days, started from grafting the seedlings of the upper and lower plants. The waterlogging treatment was given in the vegetative, flowering, and fruiting phases. Tomato plants that had been grafted were maintained to be waterlogged at the level of $5-7 \mathrm{~cm}$ above the ground. Maximum temperature was maintained at $32^{\circ} \mathrm{C}$, with a minimum temperature of $25^{\circ} \mathrm{C}$, while the maximum humidity was at $80 \%$, with a minimum humidity at $70 \%$. Observations on nutrient level in the soil included measurement of Calcium level remaining in the soil after harvest, observed at the Soil Laboratory of the Faculty of Agriculture, University of Brawijaya Malang. Observation results included the number of fruits, the weight of fruits from each plant, and the number of rotting fruits. Harvesting was done when the plants were \pm 9 weeks after transplanting.

Statistical Analysis. The data were analyzed using the analysis of various F-tests at $5 \%$ level in order to test the effect of treatments. Differences between treatments were tested using the LSD test at 5\% level. Data analysis was conducted using GENSTAT software (Version 18.2) .13.

\section{RESULTS AND DISCUSSION}

Calcium contained in the soil was not fully absorbed by the plants. The Calcium level in tomato plants grafted to either the EG 203 rootstock or Gelatik rootstock showed that the soil 
waterlogged for 4 days in the vegetative phase, the flowering, and fruiting phases caused the Calcium level to drop/lower compared to the control treatment or the tomato plants which were waterlogged for 2 days. Rootstocks (eggplants) waterlogged for 4 days could absorb Calcium in the soil more compared to the root that were waterlogged for two days and the root with no waterlogging (control treatment). More water absorption by the root was due to longer waterlogging period and higher transpiration, which in turn caused higher concentration of calcium to be absorbed. This is in accordance with the results of study by Jian De et al. (2006) on lettuce which states that irrigation can increase the Calcium (Ca) level in lettuce's leaf and can reduce the burning buds, leading to a conclusion that irrigation can prevent Calcium deficiency in vegetable crops. The distribution of Calcium in a plant is influenced by transpiration; therefore, root pressure is needed to absorb Calcium in sufficient quantity to prevent blossom end rot (Palzkill and Tibbits, 1977).

However, low soil humidity also inhibits the distribution of Calcium to plant's tissues. A factor affecting Calcium deficiency in plants is the uptake of plants that is affected by soil humidity, salinity, oxygen level, temperature and balance between anions/cations in the soil (Olle and Bender, 2009; Margit and Ingrid, 2009).

The soil used to cultivate tomato plants grafted to eggplant rootstock EG 203 shows a lower Calcium level than the soil used to cultivate plant with Gelatik eggplant rootstock. This shows that the roots of line EG 203 eggplant could absorb more Calcium than the roots of Gelatik eggplant. Calcium is one indicator that shows adaptability to environmental stresses such as leaf area addition, pigment synthesis, and membrane potential changes, which all involve enzyme synthesis through phytochrome action (Djukri, 2009). Terraza et al. (2008) find that increasing the Calcium level significantly reduces the number of blossom end rot in tomato plants.

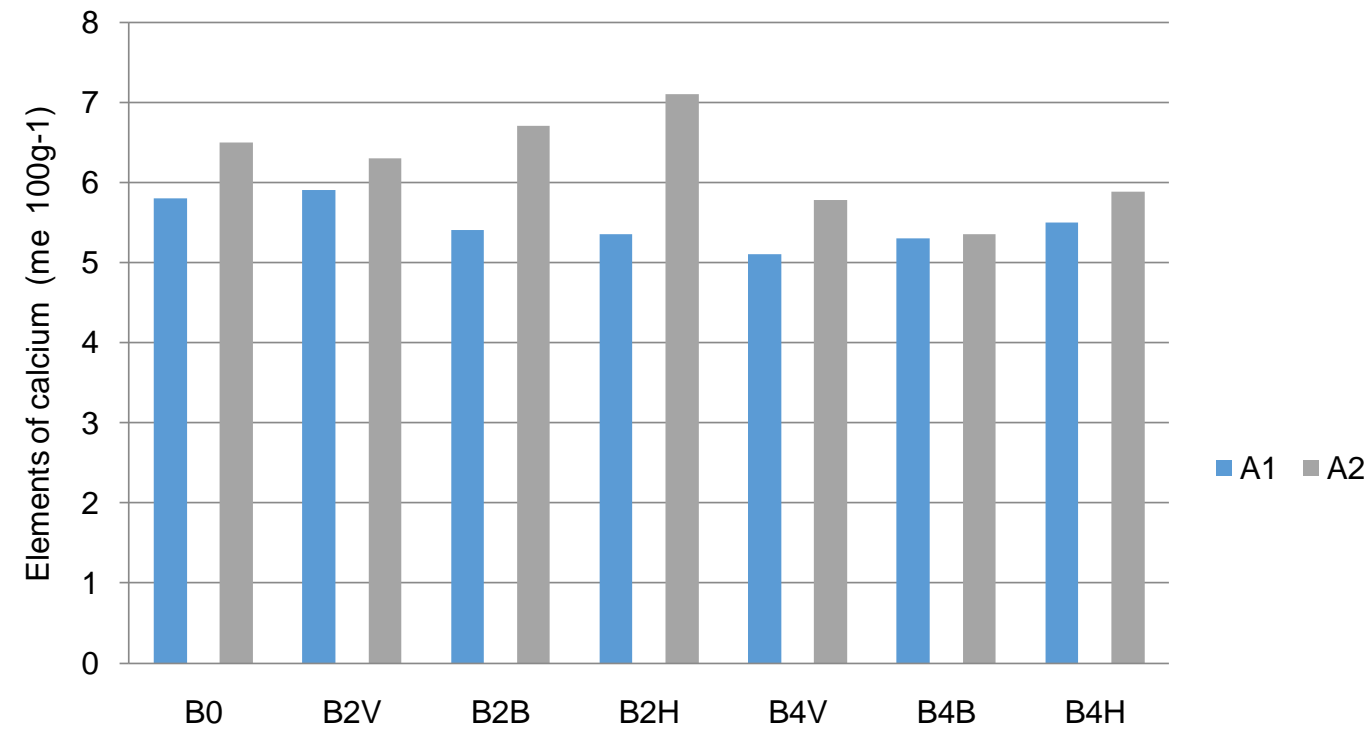

waterlogged Treatment at different phases

Figure 1 - Calcium level in soil in tomato plants grafted to two kinds of rootstock which were waterlogged at different phases. The rootstock of eggplant with EG 203 (A1) line and Batag Gelatik eggplant (A2); no waterlogging treatment (B0), 2-day-waterlogging treatment in the vegetative phase (B2V), 2-day-waterlogging treatment in the flowering phase (B2B), 2-day-waterlogging treatment in the fertilization phase $(\mathrm{B} 2 \mathrm{H})$, 4-day-waterlogging treatment in the vegetative phase (B4V), 4-daywaterlogging treatment in flowering phase (B4B), and 4-day-waterlogging treatment in the fertilization phase $(\mathrm{B} 4 \mathrm{H})$.

Fruit rot is not caused by pathogens, but is hampered by physiological processes due to low calcium level. Calcium is needed for normal cell growth and is required in relatively high concentration for new tissue growth (Nunez, 2006). Evidence that Calcium deficiency is 
the main cause of blossom end rot has been proven by Saure (2001) who finds that tomato plants grown on media containing very low $\mathrm{Ca} 2+$ often result in blossom end rot followed by chlorosis, which is necrosis of leaf edges, and inhibition of root and leaf tip growth.

Tomato plants that were grafted to Gelatik rootstock with 2-day-waterlogging treatment showed quite low calcium uptake (Figure 1), especially during the fruiting phase. Waterlogging during fruiting phase caused relatively low calcium uptake, resulting in low nutrient level which in turn affected fruit formation. This is consistent with the findings of Taylor and Locascio (2004) that indicate Calcium distribution in plants through xylem follows the flow of water transpiration from the roots up to the upper parts of the plants and to the growing leaves, where Calcium does not have the ability to flow from the leaves to the fruit through the phloem.

Table 1 - Number of fruit blossom end rot in grafted tomato plants which were waterlogged at different growth stages

\begin{tabular}{|c|c|c|c|c|c|c|c|c|c|c|c|c|c|c|}
\hline Treatment & B0 & & B2V & & B2B & & $\mathrm{B} 2 \mathrm{H}$ & & B4V & & B4B & & $\mathrm{B} 4 \mathrm{H}$ & \\
\hline$\overline{A 1}$ & $\begin{array}{l}22.8 \\
A\end{array}$ & $\mathrm{bc}$ & $\begin{array}{l}26.8 \\
A\end{array}$ & $c$ & $\begin{array}{l}19.83 \\
A\end{array}$ & $a b c$ & $\begin{array}{l}16.83 \\
A\end{array}$ & $a b$ & $\begin{array}{l}11.5 \\
A\end{array}$ & $a$ & $\begin{array}{l}15 \\
A\end{array}$ & $a b$ & $\begin{array}{l}15 \\
A\end{array}$ & $a b$ \\
\hline $\mathrm{A} 2$ & $\begin{array}{l}35.17 \\
\text { B } \\
\end{array}$ & $b$ & $\begin{array}{l}37.22 \\
\text { B }\end{array}$ & $\mathrm{bc}$ & $\begin{array}{l}25.5 \\
A\end{array}$ & a & $\begin{array}{l}46.3 \\
B\end{array}$ & C & $\begin{array}{l}21.17 \\
\text { A }\end{array}$ & a & $\begin{array}{l}19 \\
A\end{array}$ & a & $\begin{array}{l}21.3 \\
A\end{array}$ & $a$ \\
\hline BNT 5\% & & & & & & & 9.5 & & & & & & & \\
\hline $\mathrm{KK}(\%)$ & & & & & & & 21.7 & & & & & & & \\
\hline
\end{tabular}

Note: Numbers accompanied by the same lowercase letter in the same row or the same uppercase letter in the same column show no significant difference based on the LSD test at 5\% level, LSD = Smallest Real Difference; KK = Coefficient of Diversity; The rootstock of the eggplant EG 203 (A1) line and rootstocks of Gelatik eggplant (A2); No waterlogging treatment (B0), 2-daywaterlogging treatment in the vegetative phase (B2V), 2-day-waterlogging treatment in the flowering phase (B2B), 2-daywaterlogging treatment in the fertilization phase $(\mathrm{B} 2 \mathrm{H})$, 4-day-waterlogging treatment in the vegetative phase (B4V), 2-daywaterlogging treatment in the fertilization phase $(\mathrm{B} 2 \mathrm{H})$, 4-day-waterlogging treatment in the flowering phase (B4B) and 4-daywaterlogging treatment in the fertilization phase $(\mathrm{B} 4 \mathrm{H})$.

Tomato plants with rootstocks EG 203 line (A1) without waterlogging produced blossom end rot that was not significantly different from tomato plants with EG 203 lines that were waterlogged for 2 days during the vegetative, flowering, and fruiting phases. The plants also showed a tendency to have decreased number of blossom end rot when waterlogging treatment was given at the vegetative phase and then decreased in the flowering and fruiting phases. When waterlogging treatment was increased to 4 days during the vegetative, flowering, and fruiting phases, the number of blossom end rot in the fruits with EG 203 line rootstock decreased. Sergio and Elizabeth (2012) conclude that visual symptoms of fruit tissues which lack of Calcium are started in water-soaked tissue condition, which in turn causes disintegration and dehydration of tissues, resulting in a dark brown color with a depressed shape on the bottom surface of the fruit.

Tomatoes with Gelatik rootstock without waterlogging treatment produced blossom end rot that was not significantly different from tomato plants with the same rootstock which were waterlogged for 2 days during the vegetative phase, and decreased blossom end rot when waterlogging treatment was given during flowering phase. There was an increase in the number of blossom end rot fruit on tomato plants with Gelatik rootstock when waterlogged for 2 days in the fruiting phase. When waterlogging treatment was increased to 4 days, the number of blossom end rot in tomato plants grafted to Gelatik rootstock decreased and there was no significant difference between the vegetative, flowering, and fruiting phases.

The number of blossom end rot of tomato plants with EG 203 line and Gelatik rootstock, both without waterlogging or 2-day-waterlogging treatment during vegetative and fertilization phases, showed a significant difference. Likewise, there was a marked difference in the number of fruits with blossom end rot when waterlogged for 4 days in the fruiting phase. There was no significant difference in the number of blossom end rot between tomato plants that were waterlogged for 2 days during flowering phase and 4 days during vegetative and flowering phases.

Table 2 shows the effects of waterlogging on grafted tomato plants on the number of fruits of each plant. Tomato plants with Gelatik (A2) rootstock without waterlogging produced the highest number of fruits. Tomato plants with Gelatik rootstock produced low fruit weight 
when treated with 4 day waterlogging in the flowering (B4B) and fertilization (B4H) phases and this yield was not significantly different from plants waterlogged for 4 days in the vegetative phase (B4V).

Table 2 - Average Number of Fruits Produced by Grafted Tomato Plants in Different Phases

\begin{tabular}{|c|c|c|c|c|c|c|c|c|c|c|c|c|c|c|}
\hline Treatment & B0 & & $\mathrm{B} 2 \mathrm{~V}$ & & B2B & & $\mathrm{B} 2 \mathrm{H}$ & & B4V & & B4B & & $\mathrm{B} 4 \mathrm{H}$ & \\
\hline$\overline{\mathrm{A} 1}$ & $\begin{array}{l}40,3 \\
A\end{array}$ & $\mathrm{~b}$ & $\begin{array}{l}32 \\
A\end{array}$ & $\bar{a}$ & $\begin{array}{l}34,3 \\
A\end{array}$ & $a b$ & $\begin{array}{l}31,67 \\
\text { A }\end{array}$ & $\mathrm{a}$ & $\begin{array}{l}31 \\
B\end{array}$ & $a$ & $\begin{array}{l}29,33 \\
B\end{array}$ & $\bar{a}$ & $\begin{array}{l}32,22 \\
B\end{array}$ & $a b$ \\
\hline A2 & $\begin{array}{l}44,7 \\
\text { A }\end{array}$ & e & $\begin{array}{l}38 \\
A\end{array}$ & de & $\begin{array}{l}30 \\
\mathrm{~A}\end{array}$ & c & $\begin{array}{l}29,67 \\
\text { A }\end{array}$ & $\mathrm{bc}$ & $\begin{array}{l}22,7 \\
\text { B }\end{array}$ & $a b c$ & $\begin{array}{l}17,67 \\
\text { B }\end{array}$ & a & $\begin{array}{l}15,67 \\
\text { B }\end{array}$ & $a$ \\
\hline BNT & $5 \%$ & & & & & & 7,8 & & & & & & & \\
\hline KK & $(\%)$ & & & & & & 15,3 & & & & & & & \\
\hline
\end{tabular}

Tomato plants with Gelatik rootstock (A2) produced a high number of fruits in the control treatment and were not significantly different when given waterlogging treatment for 2 days during vegetative phase (B2V). Furthermore, tomato plants with Gelatik rootstock (A2) produced significantly different weight when waterlogging treatment was given for 2 days during vegetative (B2V), flowering (B2B), and fruiting (B2H) phases and for 4 days during the vegetative phase (B4V).

Tomato plants with EG 203 line rootstock (A1) produced a high number of fruits in a control treatment, which was not significantly different when given waterlogging treatment for 2 days (B2) during vegetative (B2V), flowering (B2B) and fertilization $(\mathrm{B} 2 \mathrm{H})$ phases and 4 days during vegetative $(\mathrm{B} 4 \mathrm{~V})$, flowering $(\mathrm{B} 4 \mathrm{~B})$ and fruiting $(\mathrm{B} 4 \mathrm{H})$ phases.

Table 3 - Fruit weight of each grafted tomato plant given waterlogging treatments at different growth stages (g.plant-1)

\begin{tabular}{|c|c|c|c|c|c|c|c|c|c|c|c|c|c|c|}
\hline Treatment & $\mathrm{B} 0$ & & B2V & & B2B & & $\mathrm{B} 2 \mathrm{H}$ & & B4V & & B4B & & B4H & \\
\hline $\bar{A} 1$ & $\begin{array}{l}1423 \\
\mathrm{~A}\end{array}$ & $\bar{a}$ & $\begin{array}{l}1192 \\
A\end{array}$ & $\bar{a}$ & $\begin{array}{l}1281 \\
A\end{array}$ & $\bar{a}$ & $\begin{array}{l}1169 \\
\text { A }\end{array}$ & $\bar{a}$ & $\begin{array}{l}1174 \\
\text { B }\end{array}$ & $a$ & $\begin{array}{l}1174 \\
\text { B }\end{array}$ & $\bar{a}$ & $\begin{array}{l}1243 \\
B\end{array}$ & $a$ \\
\hline A2 & $\begin{array}{l}2037 \\
\text { B }\end{array}$ & c & $\begin{array}{l}1596 \\
\text { A }\end{array}$ & $\mathrm{bc}$ & $\begin{array}{l}1359 \\
\text { A }\end{array}$ & b & $\begin{array}{l}1239 \\
\text { A }\end{array}$ & b & $\begin{array}{l}667 \\
\text { A }\end{array}$ & a & $\begin{array}{l}933 \\
\text { A }\end{array}$ & a & $\begin{array}{l}654 \\
\text { A }\end{array}$ & a \\
\hline BNT 5\% & & & & & & & 4.76 & & & & & & & \\
\hline KK (\%) & & & & & & & 23.3 & & & & & & & \\
\hline
\end{tabular}

Table 2 shows the effects of waterlogging on grafted tomato plants on the weight of fruits of each plant. Tomato plants with Gelatik (A2) rootstock without waterlogging produced the highest number of fruits. Tomato plants with Gelatik rootstock produced low fruit weight when treated with 4 day waterlogging in the flowering (B4B) and fertilization (B4H) phases and this yield was not significantly different from plants waterlogged for 4 days in the vegetative phase (B4V).

The results of the analysis showed that tomato plants grafted to EG 203 line rootstock without waterlogging yielded a fruit weight that was not significantly different from plants that were waterlogged for 2 and 4 days during the vegetative, flowering, and fruiting phases. In addition, there was a tendency for the fruit weight of every plant in the control treatment and the others which were given waterlogged treatment to decrease.

Tomato plants that were grafted to Gelatik rootstock without waterlogging produced fruit weight per plant that was not significantly different compared to tomato plants with the same rootstock and was waterlogged for 2 days during the vegetative, flowering, and fruiting phases. A longer waterlogging period of 4 days on tomato plants with Gelatik rootstock during the vegetative, flowering, and fruiting phases showed no significant difference and all experienced decreased fruit weight. Furthermore, the treatment shows a significant difference when compared with plants with control treatment and plants with 2 day waterlogging treatment in all phases.

There was a difference in plant fruit weight in different rootstock treatments. Tomato plants with EG 203 rootstock showed differences in plant fruit weight compared to tomato plants with Gelatik rootstock without waterlogging. Tomato plants with Gelatik rootstock produced higher fruit weight when waterlogged for 2 days in the vegetative and fertilization 
phases. The same thing can be seen in the plants with 4 day waterlogging treatment in the fruiting phase which yielded large number of rotten fruit. Tomato plants with EG 203 rootstock which was waterlogged for 2 days during flowering phase and 4 days during vegetative and flowering phases did not experience any significant difference with the other rootstock type.

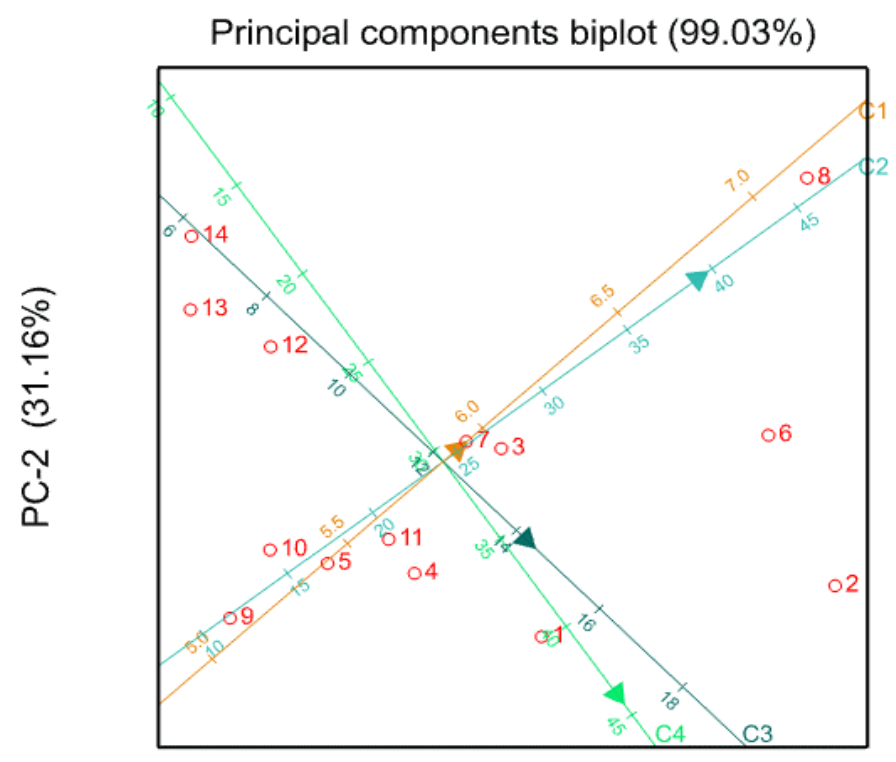

PC-1 (67.88\%)

Figure 2 - Analysis of the main components of the biplot from grafting tomatoes which were waterlogged in various phases. Based on the value of the variables produced, a positive correlation was generated in group I (top right) consisting of C1 (calcium content) and C2 (number of blossom end rot). Correlation with variables in group II (bottom right) consists of C3 (weight of fruit per crop) and C4 (number of fruits).

Biplot analysis shows that the total diversity obtained was quite high at $99.03 \%$; therefore, the Biplot results obtained are quite representative (Figure 2). The Calcium level remaining in the soil during the waterlogging treatment at different phases affected the amount of blossom end rot produced because the angle formed between these two variables was small and less than $90^{\circ}$. This shows a very strong and positive correlation between the remaining Calcium levels in the soil with the amount of blossom end rot of the tomato fruits produced. The calcium level remaining in the soil was low and consequently the number of blossom end rot in the plants was also low. This is due to the low Calcium level remaining in the soil and the high Calcium absorbed by plants which results in the fulfillment of the Calcium requirement, causing a low number of rotten tomatoes.

Variation of variables between the Calcium level in the soil and the fruit weight of the crop and the amount of fruit produced is positively correlated because the angle formed is around $90^{\circ}$, showing a low correlation of fruit weight and fruit yield.

\section{CONCLUSION}

Tomato plants grafted to two kinds of rootstock, namely EG 203 line and Gelatik variety which were waterlogged for 4 days, benefitted from the treatment because Gelatik eggplant roots could absorb more Calcium, so as to reduce the number of blossom end rot on the base of the tomato fruit. Furthermore, tomato plants with EG 203 line as rootstock had better ability to absorb Calcium than tomato plants grafted to Gelatik rootstock under both normal condition and waterlogging treatment for 2 days in several phases. 


\section{REFERENCES}

1. Abdelmageed, A.H. A and N. Gruda. 2009. Influence of grafting on growth, development and some physiological parameters of tomatoes under controlled heat stress conditions. European Journal of Horticultural Sciences, 74(1):16-20.

2. Adam, P. And Ho. 1992. The susceptibility of modern tomato cultivars to blossom end rot in relation to salinity. J. Hort. Sci. 67:827-839.

3. Bartal, A. and Pressman, E. 1996. Root restriction and potassium and calcium solutions concentrations affect dry matter production, cation uptake and blossom end rot in greenhouse tomato. J. Am Soc. Hort. Sci. 121: 649-655.

4. Djukri. 2009. Regulasi ion kalsium (Ca++) dalam tanaman untuk menghadapi cekaman lingkungan. Prosiding Seminar Nasional Penelitian, Pendidikan and Penerapan MIPA, Fakultas MIPA, Universitas Negeri Yogyakarta, 16 Mei 2009. B.56-61.

5. Hao, 2003. Effects of calcium and magnesium on growth, fruit yield and quality in a fall greenhouse tomato crop grown on rockwool. Can. J. Plant Sci. 83 (1): 903-912.

6. Hartmann, H., D. Schwatz. 2009. Interactive effects of grafting and manganese supply on growth, yield and nutrient uptake by tomato. Horticultural Science, 44 (7):1978-1982.

7. Ikeda, H., 1988. The effect of $\mathrm{NO} / \mathrm{NH}$ ratios and temperature of the nutrient solution on growth, yield and blossom end rot incidence in tomato. J. Jpn. Soc.Hort Sci. 57:62-69.

8. Jian DE. H., Wen Quiang, W. and Ming Shan, Q. 2006. Effects of different irrigation and fertilizer on $\mathrm{Ca}$ absorbstion and tip burn of lettuce. China Veg (6). Institute of Vegetable and Flowers, Beijing. P. R. China. 1(1):11-13.

9. Marcelis, L.F.M., Ho, LC. 1998. Blossom-End rot in relation to growth rate and calcium contents in fruits of sweet pepper (Capsicum annuum L). J. Exp. Bot. 50: 357-363.

10. Nonami, H., 1995. Blossom-end rot of tomato plants may not be directly caused by calcium deficiency. Acta Hort. 396: 107-114.

11. Nunez, J. 2006. Blossom end rot due to calcium deficiency. https://www.farmprogress.com/blossom-end-rot-due-calcium-deficiency/.

12. Olle, M. and I. Bender. 2009. Causes and control of calcium deficiency disorders in vegetables: a review. Journal of Horticultural Science \& Biotechnology. 84 (6): 577-584.

13. Palzkill, D. A., Tibbits, T. W. 1977. Evidence that root pressure flow is required for calcium transport for head leaves of cabbage. Plant Physiology. 60: 854-856.

14. Petropoulos, S.A., E.M. Khah and H.C. Passam. 2012. Evaluation of rootstocks for watermelon grafting with reference to plant development, yield and fruit quality. International Journal of Plant Production, 6(4):481-489.

15. Raigon, M. D., Prohens, J., Mufioz Falcon and F, Nuez. 2008. Comparison of eggplant landraces and commercial varieties for fruit content of phenolics, minerals, dry matter and protein. J of food Composition and Analysis. 21 (1): 370-376

16. Ruiz, J. M. 1997. Leaf macronutrient content and yield in grafted melon plants. A model to evaluate the influence of rootstocks genotype. Sci Hortic. 71: 227-234.

17. Saure, M. C. 2001. Blossom end rot of tomato (Lycopersicon esculentum Mill.) a calcium - or a stress-related disorder. Sci. Hort. 90 (1): 193-208.

18. Sergio, T. D. Freitas and Elizabeth, M. 2012. Factor involved in fruit cacium deficiency disorders. Horticultural Reviewers. 40 (1): 107-146.

19. Sonneveld and Voogt. 1991. Effect of Ca-stress on blossom-end rot and Mg-deficiency in rockwool grown tomato. Acta Hort. 294: 81-88.

20. Suntoro, Jauhari, S., and Widyas Rahina. 2017. Ketersediaan and serapan Ca pada kacang tanah di tanah Alfisols yang diberi abu vulkanik Kelud and pupuk kandang (Availability and uptake of calcium in peanuts in Alfisols soils that are treated with Kelud volcanic ash and manure). Agrosains 19(2): 1411-5786.

21. Taylor, M.D. 2004. Blossom end rot: Calcium deficiency. J. Plant Nutr. 27 (1): 123-139.

22. Terraza, S. P., Romero, M.V., Pena, P.S, Madrid, J. L. C and Verdugo, S. H. 2008. Effect of calcium and osmotic potential of the nutritive solution on the tomato blossom- end rot, mineral composition and yield. Interciencia. 33(1):449-456.

23. Willumsen, J. Petersen K.K and Kaack, K. 1996. Yield and blossom end rot of tomato as effected by salinity and cation activity ratios in the root zone. J. Hort Sci. 71: 81-98. 